\title{
A New Thinking on the Driving Force of Social Development
}

\author{
Gao Peng \\ School of Humanities \\ Tongji University \\ Shanghai, China 200092
}

\begin{abstract}
This paper mainly proposes a new thinking about the driving force of social development. The driving force of social development is the "three-in-one" system with human selftranscendence as the motive force and theoretical innovation and practical innovation as the two fundamental driving forces. This system also follows the fundamental principle of unity of regularity and purpose.
\end{abstract}

Keywords - the driving force of social development; "three-inone" system; human self-transcendence essence; theoretical innovation; practice innovation

\section{INTRODUCTION}

Based on the analysis of the current research status of driving force of social development in domestic academic circles, the author finds that the current research on the initial force or the motive force of social development in domestic academic circles is not deep enough. In view of this, in this paper, based on the reference and reflection of the above research results, the author puts forward a new thinking on the driving force of social development, in order to deepen the understanding of this issue.

\section{THE THEORETICAL BASIS AND REALISTIC}

BACKGROUND OF THE NEW THINKING ON THE DRIVING FORCE OF SOCIAL DEVELOPMENT

\section{A. The Theoretical Basis for the New Thinking on the Driving Force of Social Development}

1) Marx and Engels' thoughts on the driving force of social development: According to the analysis of classic works of Marxism, Marx and Engels' ideological views on the driving force of social development mainly include the following nine aspects: human needs or interests are the ultimate driving force of social development; social practice is the fundamental foundation of social development; productivity is the basic driving force of society development; Basic social contradictions are the basic driving force of social development; class struggle is the direct driving force of class society development; the masses of the people are the main driving force of social development; "Unity of history" is the systemic driving force of social development; opening to the outside world is the external driving force of society development; science and technology are important driving force of social development. These nine aspects are inseparable from the essence of human self-transcendence. First, human needs or interests are the ultimate driving force of social development. The reason why people's needs and interests can become the ultimate driving force of social development is that people have the essence of selftranscendence. Because of this, people can transcend their basic material needs, yearning for and pursue a better living and social situation, and then they will resort to social practice activities, promoting technological innovation and progress as well as the productivity and production relations, contradictory movements between economic foundation and the superstructure, while actively engaging in social interaction, struggling in class society to change social relations, thereby promoting the continuous development and progress of society; Second, social practice is the fundamental foundation of social development; the main body of social practice is People, and people's social practice can promote the development of society, this practice must be an innovative practice. The reason why innovative practice can happen is that people have the consciousness and ability of innovation, and this kind of innovative consciousness and ability is rooted in the essence of human self-transcendence. Third, productivity is the fundamental driving force of social development; the reason why productivity can become the basic driving force of social development is that productivity has certain creativity in its essence, and repetitive production at a certain fixed level cannot promote social development. And the creativity of productivity is not created out of thin air. The most active factors and subjects in productivity are people, and the creativity of productivity comes from people. And human creativity is rooted in the essence of human selftranscendence. Fourth, the basic social contradiction is the basic driving force of social development. The basic contradiction of society is the contradiction between productivity and production relations, economic foundation and superstructure. This contradiction can become the basic driving force of social development because it has certain transcendence and creativity in essence. If the specific components of this contradiction always stop at a certain fixed level and condition, and repeat the cycle, then it will not promote the development of society. Of course, the 
transcendence and creativity of this contradiction are not produced out of thin air. The root of this contradiction lies in the nature of human self-transcendence. The subject is still human in this contradiction. People are the most active factor in the productivity system, and productivity is the decisive factor in this contradiction. Therefore, the reason why this contradiction has transcendence and creativity is rooted in the essence of human self-transcendence; fifth, class struggle is the direct driving force of class society development. The reason why class struggle can promote social development is that, compared to the old class, the new class have transcendence and creativity and thus can replace the old class in class struggle and win in class struggle. In addition, precisely because of transcendence and creativity, the new class can accurately predict the trend of social development, grasp the trend of social development, and thus conform to the trend of social development, and carry out some scientific and rational, pragmatic and effective social practice activities to promote the development of society. The transcendence and creativity of the new class are not created out of thin air, and the class is also made up of people. The transcendence of the new class is still rooted in the essence of human selftranscendence; sixth, the masses of the people are the main driving force of social development. The reason why the people can become the main driving force of social development is that it has the essence of self-transcendence. Therefore, they will not be satisfied with their existing living conditions and the real state of society, and will always create a vision and awkwardness for a better life and a more ideal social state, and put into social practice activities to improve their lives and promote the development of society; seventh, "health of history" is the systemic driving force of social development. "Unity of history" is mainly to say that the development of history is the result of the synergy of the desires of many different individuals and their overlapping effects on society. The "unity of history" has become a systemic driving force of social development, because in this "unity", the individual desires of transcendence, progress and creativity and their role in society account for the vast majority. Thus, it has occupied a dominant position in this "combination force" and played a major decisive role in the direction of social change, thus being able to lead and promote the development of society. The roots of these transcendental, progressive and creative individual desires and their role in society are still rooted in the essence of human self-transcendence; eight, opening up is the external driving force of social development. The reason why the opening up to the outside world can become the external driving force of social development depends on its main body-the human being. The reason why people can open to the outside world is that they have the essence of self-transcendence. Therefore, it can transcend the narrowness of its own vision, be able to communicate with the outside world, communicate and interact with the outside world, exchange resources in the material resources and ideology and culture, and learn from each other to promote the development of society; It is an important driving force for social development. Ninth, science and technology are important driving force of social development. The reason why science and technology can become an important driving force for social development is that technology can continue to innovate according to the needs of changing social development. The reason why technological innovation can happen depends on the innovation consciousness, innovation ability and innovative practice activities of scientific and technological talents. The root of the scientific and technological talents' innovative consciousness and ability to carry out innovative practice activities lies in the nature of human self-transcendence. It is precisely because of this essence that people can generate a sense of innovation, in order to continuously deepen their understanding of the laws of nature, society and thinking, and then generate and enhance the ability, thus continuously promoting the innovation of science and technology.

2) The philosophy of hope in Western Marxism: In the history of the development of Western Marxism, the famous thinker Ernst Bloch established the unique philosophy of hope. The core is that the essence of human beings is selftranscendence. He pointed out that we must have a sense of hope for a better society in the future, show the essence and ability of self-transcendence, promote the perfection and development of society through self-transcendence, and gradually realize a beautiful communist society.

3) Socialism with Chinese characteristics in new era of $X i$ Jinping: Socialism with Chinese Characteristics in New Era of $\mathrm{Xi}$ Jinping has a rich connotation. Based on the research topic of this article, the author focuses on and thinks deeply about the following ideas.

a) Discussion on the Chinese Dream: The essence of the Chinese dream is the prosperity of the country, the rejuvenation of the nation and the happiness of the people. [1] It can be seen that the Chinese dream is an ideal for a good life. The Chinese dream is ultimately the dream of the people. [2] The reason why the Chinese dream can be raised is still the people's longing for a better life. The reason why people have a yearning for a better life is that people have the essence of self-transcendence. It is people who have this essence that the people can surpass their current status of survival and development and the state of social development, and envision a better life. In short, the Chinese dream also reflects the essence of human self-transcendence. Only working hard can make a dream come true. [3] The "hard work" here cannot be a practical activity of standing still and repeating the cycle at a certain level, but must be a transcendence and creative practice. Transcendence and creative practice activities are inseparable from human innovation consciousness and ability. The reason why human consciousness and ability can be produced is rooted in the self-transcendence essence of human beings. In short, the introduction and realization of the Chinese dream are inseparable from the essence of human self-transcendence. 
b) Discussion on ideal beliefs: The ideal and belief is the spiritual "calcium" of the Communists. [4] The ideal belief is not only the "calcium" of the spirit of the Communist Party, but also the indispensable part of everyone's life, because the ideal and belief itself also reflects the self-transcendence essence of human beings. The ideal comes from reality and is higher than reality. The reason why people can transcend reality and produce ideals above the level of reality is that people have the essence of self-transcendence, so that they can surpass the social status quo and envision a better life state and social state in the future, that is, ideals.

c) The initial heart and mission of the Chinese Communists: The initial intention and mission of the Chinese Communists is to seek happiness for the people and to revive the nation. [5] The initial heart and mission of the Chinese Communists is the spiritual impetus to inspire the generations of Chinese Communists to work tirelessly. This initial heart and mission also embodies the essence of human selftranscendence. It is precisely because of this essence that the party's pioneers can transcend the narrow interests of individuals and the boundaries of survival and development, establish a lofty ambition of taking the world as their own responsibility, and rejuvenate the nation without fear of sacrifice and hard work; precisely because of this essence, they can create a yearning and vision for the future beautiful society beyond the nature and condition of society at that time, and strive to achieve this beautiful society.

\section{B. The Realistic Background of the New Thinking of Social Development}

1) The emergence of value nihilism: Nietzsche believes that nihilism is the depletion of the highest value. The value nihilism is an important manifestation of nihilism. In today's Chinese society, the trend of value nihilism is more obvious. One of the outstanding manifestations of value nihilism is the loss of lofty values and lofty ideals. Some people have relaxed their adherence to values in their lives, and they have also reduced their pursuit of the goal of lofty ideals. They are more just pursuing the satisfaction of their present material life, not thinking about their future development, and not caring about the development and progress of society. In addition, some people even have a negative attitude towards life. The online hot word "Buddha Youth" is one of the manifestations of this mentality. The spread of value nihilism blinds people's selftranscendence essence, which makes people lose the motivation for self-improvement and development, and then it is difficult to promote the long-term development of individuals and the sustainable development of society. To fight against the nihilism of value and save the ideological state of society, we must re-energize the essence of human self-transcendence.

2) Tool rationality is popular: In today's society, tool rationality is popular. One of the manifestations is the prevalence of pragmatism, which is caused by the usefulness principle of tool rationality. The core principle of usefulness emphasizes "usefulness and truth." The core of pragmatism is that everything is based on the principle of being useful and pursuing "usefulness is truth." Under the influence of pragmatism, many people use their ideas or actions as a starting point for whether things or things are useful. In their view, useful things are worth pursuing, and useful things are worthy of action. The danger of pragmatism cannot be ignored. It makes tool rationality dominate people's thinking mode, value concept and behavior mode. Value rationality is forgotten and suppressed, which blinds people to the essence of self-transcendence and loses both thought and action in transcendence, and thus it is difficult to promote the overall development of the individual and the overall development of society. In addition, another principle of tool rationality is the accuracy and computability of behavior. This principle is also popular in today's society, and its harm cannot be ignored. It makes people's thoughts and behaviors be governed by the principles of precision and computability, and thus loses criticality and transcendence, and thus it is difficult to promote the healthy development of individuals and the overall development of society. Therefore, for the all-round development of society, we must awaken people's selftranscendence essence to counter the popular tool rationality.

3) Materialized consciousness is increasingly rampant: In today's society, due to the negative effects of the development of commodity economy and the influence of certain negative values in Western society, many people's consciousness is occupied by material interests and material enjoyment. They are addicted to chasing material interests and material enjoyment, and are deeply immersed in fetishism without knowing it. In the process of excessive pursuit of material interests and material enjoyment, they lost their ideals and beliefs, lost their self-transcendence consciousness, and blinded the essence of self-transcendence. Such social thoughts and mentality are not conducive to the overall development of individuals or the overall development of society. Therefore, we must awaken people's selftranscendence essence to counter the increasingly materialized materialization consciousness, thus promoting the all-round development of individuals and society.

\section{THE "THREE-IN-ONE" DRIVING FORCE SYSTEM OF SOCIAL DEVELOPMENT}

Through the above analysis of the theoretical basis and the realistic background, the author has formed a new thinking on the driving force system of social development, and formed a "three-in-one" driving force system of social development. The specific content of this system is: social development takes the self-transcendence essence of human beings as the motive force, and the positive interaction of theoretical innovation and practical innovation is the fundamental driving force. These three elements complement each other and interact positively, which constitutes the power system of social development. The self-transcendence nature of human beings promotes people's theoretical innovation and practical innovation, and then promotes the development of society. 


\section{A. Motive Force: the Essence of Human Self-transcendence}

As the motive force of social development, the selftranscendence essence of human beings is based on the indepth analysis of the ideological views of classical writers such as Marx and Engels on the driving force of social development. According to the analysis of classic works of Marxism, Marx and Engels' ideological views on the driving force of social development mainly include the following nine aspects: human needs or interests are the ultimate driving force of social development; social practice is the fundamental foundation of social development; productivity is the basic driving force of society development; Basic social contradictions are the basic driving force of social development; class struggle is the direct driving force of class society development; the masses of the people are the main driving force of social development; "Unity of history" is the systemic driving force of social development; opening to the outside world is the external driving force of society development; science and technology are important driving force of social development. Among the above nine aspects of motivation, people are the main body. In other words, the development of society ultimately depends on people. People are the mainstay of social development, and the root of human beings is the main body of human development. It is precisely because of this essence that the human subject can transcend its existing conditions of survival and development, produce a yearning for a better life and development of its own, and a vision of a better social state, and then put it into social practice to promote the development of productive forces, change social relations (class struggle in class society), promote basic social contradictions, promote the development of science and technology, conduct social exchanges, and promote social development.

In short, society is made up of people. The development of society ultimately depends on people. The essence of human self-transcendence is the motive force of social development. Only by fully exerting the essence of self-transcendence can people promote their own long-term development and the sustainable development of society.

\section{B. Fundamental Force: Positive Interaction Between Theoretical Innovation and Practical Innovation}

Society is made up of people. People are the mainstay of social development. The development of society is not a completely spontaneous historical process. On the one hand, it requires theoretical guidance, and on the other hand, it needs to be promoted by practice. Therefore, in order to promote the development of society, people must also carry out two basic activities: theory and practice. Theories and practices that promote social development must be innovative. If theoretical research can only stop on the basis of past or present theoretical results, then it is unable to adapt to the actual needs of social development. Theory must advance with the times, that is to say, theoretical innovation must be carried out according to the social development and the needs. Again, practice is the same. If practice only degenerates into a repetitive human activity, then it cannot promote social development. The essence of development lies in metabolism and new things replace old things. The development of society itself means real-time renewal of the social outlook. Therefore, in order to promote the sustainable development of society, practice and innovation must be endless, and theoretical innovation must be endless. The reason why people can carry out theoretical innovation and practice innovation lies in the essence of human self-transcendence. Because of this essence, people can transcend themselves and the boundaries of the existing state of society, generate a sense of innovation, and then deepen the understanding of nature, society and the law of thinking, generate and enhance the ability of innovation, and thus continue to promote theoretical innovation and practice innovation. .

\section{THE "ThreE-IN-ONE" DRIVING ForCE SySteM Must FOLLOW THE PRINCIPLE OF UNITY AND PURPOSE}

This "three-in-one" driving force system must follow the objective law of the unity of regularity and purpose. On the one hand, human self-transcendence essence, theoretical innovation and practical innovation must conform to objective laws, which embody the regularity. Freedom cannot get rid of necessity; freedom is bounded and based on necessity. Without necessity, and there is no freedom. There is a dialectical unity and inseparable relationship between the two. Although the self-transcendence essence of human beings must transcend its own and the existing conditions of social development, it cannot violate the objective laws. Otherwise, it will encounter setbacks in social practice and cannot effectively promote its own and social development. Theoretical innovation and practical innovation must not only break the rules, but also follow objective laws. These objective laws include the natural world, human society and human thinking; on the other hand, human self-transcendence essence, theoretical innovation and practical innovation must also conform to human purposes. The purpose of human self-transcendence serves the purpose of human beings, and theoretical innovation must reflect the purpose of human beings, and the practice and innovation must satisfy the purpose of human beings. This reflects the purpose. Of course, the purpose of the human beings is not produced as desired or for no reason. The purpose of the person must conform to the objective law. The purpose that violates objective laws will cause social practice to suffer setbacks and make it difficult to achieve its value in social practice. Therefore, the "three-in-one" driving force system must also follow the objective laws that are consistent with the regularity and the purpose and law. Only in this way can it give full play to the promotion of social development.

\section{CONCLUSION}

The new model of the "three-in-one" driving force system is just a new thinking of the author on the driving force of social development based on social reality. This new thinking does not deny the social development dynamics theory of the classic Marxist writers, nor does it deny the ideological views of the party's various generations of collective leadership on the dynamics of social development since the founding of New China. Just based on today's social reality and society, a new thinking on the issue of developmental dynamics is formed.

In the reality drama of social development, people are both playwrights and characters. Society is made up of people. People live and develop in society, so people and society are inseparable. The masses of the people are the creators of 
history and the mainstay of social practice. The practice of the people promotes the development of society. Vibrant and creative socialism was created by the people themselves. [6] In other words, the masses of the people are also the mainstay of socialist construction. At present, China has entered a new era of socialism with Chinese characteristics and is in the stage of decisive victory in building a well-off society in an all-round way. To fully build a well-off society and promote the development of the cause of socialism with Chinese characteristics in the new era, we must give full play to the main role of the people. At present, it is timely to establish people-centered development thinking. We must believe in the people and rely on the people to let them fully contribute wisdom and strength in socialist construction, so as to comprehensively build a well-off society and promote the development of socialism with Chinese characteristics. In addition, from the long-term term, in order to realize the great rejuvenation of the Chinese nation, we must also play the main role of the people of the whole country and rely on the courage and unremitting struggle of the people of the whole country.

It is necessary to give full play to the main role of the people in building a well-off society in an all-round way. To promote the development of the cause of socialism with Chinese characteristics in the new era and realize the great process of the rejuvenation of the Chinese nation, the prerequisite is to establish a firm ideal and belief because thought is the forerunner of behavior. Only by establishing a solid ideal and belief can the people consciously contribute wisdom and strength to building a well-off society, promoting the development of socialism with Chinese characteristics in the new era, and realizing the great rejuvenation of the Chinese nation. To let the people establish a firm ideal and belief, we must inspire the self-transcendence of the people. Only the people's self-transcendence essence is motivated, can they surpass their own survival and development and the reality of social development, produce social ideals higher than reality, and carry out theoretical innovation and practical innovation to promote this ideal.

In short, in the new era of socialism with Chinese characteristics, in order to promote the development of society, it is necessary to inspire the self-transcendence essence of people, so that they can establish a firm ideal and belief, and then exert their enthusiasm, initiative and creativity to guide and support them. Carrying out theoretical innovation and practical innovation to promote the sustained and healthy development of socialism with Chinese characteristics in the new era, build a comprehensive well-off society, and gradually realize the great rejuvenation of the Chinese nation.

\section{REFERENCES}

[1] General Secretary Xi Jinping's Important Speech Reader (2016 Edition) [M]. Learning press、People's Publishing House,2016 Edition,Page 8.

[2] General Secretary Xi Jinping's Important Speech Reader (2016 Edition) [M]. Learning press、People's Publishing House,2016 Edition,Page 8.

[3] Xi Jinping talks about governing the country (Volume I) [M]. Foreign languages press,Edition 2 in January 2018,Page 48.

[4] General Secretary Xi Jinping's Important Speech Reader(2016 Edition) [M]. Learning press、People's Publishing House,2016 Edition,Page 106.
[5] Winning a Comprehensively Completed Well-off Society and Winning the Great Victory of Socialism with Chinese Characteristics in the New Era - Report at the 19th National Congress of the Communist Party of China[Z]. People's Publishing House,Edition 1 in October 2017,Page 1.

[6] Lenin's Complete Works (Volum. 26) [M]. People's Publishing House,Edition 1 in December 1955. 